National Certificates in Applied Physics was published during the year. The Monographs for Students series, which was originally associated with the Higher National Certificate courses, has been broadened to extend to undergraduate and postgraduate students, and two volumes, Automatic Control, by A. E. DeBarr, and Viscosity and its Measurement, by A. Dinsdale and F. Moore, together with a third edition of Errors of Observation and Their Treatment, by J. Topping, were published. In October, Edward Arnold (Publishers), Ltd., issued for the Institute and Society the sixth compilation from the Journal of Scientific Instruments by Dr. Ruth Lang of Laboratory and Workshop Notes 1959-61. As formerly. the royalties from this volume are donated to the Institute and Society's Benevolent Fund.

A large portion of the annual report is devoted to the discussions and recommendations of the Publications and Finance Committees in relation to the three monthly periodicals, Proceedings of the Physical Society, British Journal of Applied Physics and Journal of Scientific Instruments, published by the Institute and Society. Certain changes were recommended, details of which have been noted (Nature, 200,$523 ; 1963)$. The annual volume of Reports on Physics for 1962 was not published until July, mainly because the articles received were somewhat longer than had been requested. The Bulletin contained 33 main articles and 143 book reviews. At the invitation. of the Royal Society's British National Committee for Physies, the Institute and Society organized an international conference on "The Physies of Semiconductors" This was held at the University of Exeter during July 16-20, and the international conference on "The Ionosphere" to which the Physical Society had agreed before amalgarnation was held at the Imperial College of Science and Technology, London, during July 2-6. The Proceedings of both these conferences have now been published and were ready for distribution by Chapman and Hall, J.td., early in 1963.

The activities of the Australian, New Zealand, Malayan and nine Great Britain branches, together with those of the ten specialist groups of the Institute and Society, are summarized in the report. With the support and encouragement of the Council, the Australian branch became the independent Australian Institute of Physics during the year. The inaugural meeting was held on August 21, 1962, and the Institute was duly incorporated on February 21, 1963. The Australian branch was dis. solved on February 28, 1963, and its assets were handed over to the Australian Institute. Following a request by members of the Institute and Society resident in Now Zealand, the Council approved the formation of a New Zealand branch. The Liverpool and North Wales Branch, joined with the Education Group in arranging a two-day conference on "The Teaching of Solid-state Physics" during Easter at the University of North Wales, Bangor. The Group also held a one-day symposium on "The Teaching of Medical Physies". The Electronies and Optical Groups collaborated in a joint two-day conference on "Optical Masers" at University College, London, and in November the Electronies and Low 'Temperature Groups held a half. day meeting devoted to solid-state masers. The Electron Microseopy Group changed its name to that of Electron Microseopy and Analysis Group to take into account increased interest in electron probe microanalysis. Consideration was given to the training of electron microscopists and in consequence two summer schools on electron microscopy have been planned. The Materials and Testing Group included in its programme four one. day symposia and the Spectroscopy Group held a twoday conference in July at Buxton on "Spectroscopy in the Metallurgical Industry" with eight invited speakers. This was followed by an Oetober meeting on "Space Spectroscopy" with two of the invited speakers coming from the United States.

The forty-sixth annual exbibition of scientific instruments and apparatus was held in the Royal Horticultura Society's Halls, London, during January 15-19, 1962. It is hoped, by refereeing exhibits submitted for futur. exhibitions, to ensure that the exhibition is an impor tant scientific occasion rather than a commercial display. It has been arranged to hold the oxhibitions from time to time outside London, and the first of these will be in 1965 when the exhibition will be in Manchester. During the year under review the Council decided to dispose of its collection of scientific periodicals, ancl the offer made by the University of Leicester for the whole collection was accepted.

\section{S. WeINTROYR}

\title{
RESEARCH AND DEVELOPMENT IN AMERICAN INDUSTRY
}

$\mathrm{T}$ THE U.S. National Science Foundation has evolved a programme to obtain annual data on the volume of research and development as measured in terms of funds and manpower. These surveys cover all major sectors of the economy - industry, Government, universities and other non-profit-making institutions. A bulletin reports the findings of the latest survey of industrial firms (Reviews of Data on Research and Development, 40 ; September 1963).

The employment of research and development scientists and engineers in industrial firms, on a full-time-equivalent basis, totalled 339,400 in January 1963 . This represented a 6 per cent increase over the comparable total of 319,800 in January 1962. Nearly all the individually reported industries showed increases in the employment of research and development scientists and engineers from January 1962 to January 1963.

In 1962, funds for industrial research and development amounted to 11.6 billion dollars, which lalso represented a 6 per cent increase over the 10.9 billion dollars reported for 1961. The 1962 total was more than three times as great as the $3 \cdot 6$ billion dollars total for 1953 . Industrial firms accounted for nearly three-quarters of the nation's total research and development performance of about 16 billion dollars in 1962 .
Federally financed research and development performed by industrial firms amounted to 6.7 billion dollars in 1962 , almost five times the 1.4 billion dollars for 1953. These funds were 58 per cent of the total funds for industrial research and development performance in 1962. Federal funds for industrial research and devolopment performance in 1962 were 7 per cent higher than the $6 \cdot 3$ billion dollars reported for 1961. The Federal Government, however. was expecting to increase its funds for research and development work performed by industrial firms at a faster rate during 1963. A substantial increase in Federal obligations for research and development to industry in the fiscal year 1963 over the fiscal year 1962 was envisaged. The Federal Government was also expecting to continue its heavy expenditures on researeh and development projects related to space exploration and defence throughout the remainder of the decade. A main portion of this Federal research and development would be conducted by industrial firms.

Of the separately reported industries, the aircraft and missiles industry and the electrical equipment and communication industry continued to play the predominant part in federally financed industrial research and dovelopment performance, although the professional and scientific 
instruments industry and the chemical industry and applied products reported greater relative increases in the federally financed portion of their research and development performance between 1961 and 1962. The 3.8 billion dollars for Federal research and development projects in the aireraft and missiles industry and the 1.6 billion dollars in the electrical equipment and communication industry together accounted for 80 per cent of federally finaneed industrial research and development performance in 1962.

Research and development performance by company funds totalled 4.8 billion dollars in 1962, or 6 per cent higher than the $4 \cdot 6$ billion reported for 1961. Company funds for industrial research and development performance more than doubled between 1953 and 1962. Company funds as a percentage of total research and development performance funds, however, declined from 61 per cent in 1953 to 42 per cent in 1962, reflecting the large increases in Federal funds during this period.

Funds for basic research performance in industry amounted to 361 million dollars in 1962, an increase of 14 per cent over the 1961-level. During 1962, industrial basic research comprised 4 per cent of total industrial research and development performance. Basic research funds increased 205 per cent between 1953 and 1962 .

\section{EXPLORATORY DRILLING FOR OIL IN SUSSEX}

$\mathrm{N}$ ATURAL gas was first observed in a water well at Hawkhurst, just across the border in Kent, in 1836. It was mot with in the two sub-Wealden boreholes put down by the Sub-Wealden Exploration Committeo of the British Association for the Advancement of Science near Mountfield, in 1872-76. These classic explorations incidentally led to the discovery of gypsum in the Purbeck beds in Sussex, the freshly broken minoral in many instances then, and as mined to-day, smelling strongly of petroleum. In 1896 a borehole for watering the then London, Brighton and South Coast Railway locomotives was made at Heathfield Station; it was $377 \mathrm{ft}$. deep, penetrating $38 \mathrm{ft}$. of Purbeck beds, and resultod in no worth-while water-supply; to compensate there was a strike of natural gas which at the time issued at a pressure of $140-200 \mathrm{lb}$./in. ${ }^{2}$; it was of sufficient volume to ignite to a flame $16 \mathrm{ft}$. high, but in 1922 the best it could do was 3-4 ft. high, although still at that time being used for some station lighting. It was this Heathfield strike which first directed public attention to natural gas possibilities in Sussex. During 1897-99 the original deep Penshurst borehole, near Tonbridge, Kent, also proved Purbeck gypsiferous beds, and it is recorded that: "The shales associated with the gypsum were often bituminous, and all the beds smelt strongly of petroloum" (Lamplugh and Kitchen, 1911). Prospecting in a commercial sense in Sussex may be said to have startod in 1902 with trial boreholes put down in the Heathfield-Mountfield-Battle area, during the 1907-9 phase of operations by the South Eastern Development Syndicate, Ltd., near Battle. Natural gas was discovered in many of these attempts, but nowhere in commercial quantity. Thereafter, furthor exploration for this purpose was abandoned and it is only within comparatively recent years that oil and gas potentialities of the sub-Wealden rocks of the south-coast countios, in particular, Sussex, Hampshire and Dorset, have been prominent in the exploration programmes planned for Great Britain by oil companies. Among the deep boroholes constructed during 1936-38 was another at Ponshurst; one at Grove Hill, Hellingly; one at Henfield; another deep-well sito near Brightling was explored in 1957, and now in 1963 there has been completed the 8,000 -ft. borehole at Bolney, noar Cuckfield.

This Bolney well was only 'spudded in' in May 1963; its complotion, actually to a depth of $8,006 \mathrm{ft}$., within a few months, is in itself a tribute to the efficiency of modern oil-well drilling oquipment and especially to the highly skillod enginoors concerned with this project. "By midA.ugust the woll at Bolney had already passed a depth of 7,000 feet and was drilling through the remains of the world of more than 300 million years ago. It was cutting through what the geologist called a marine formation of the Devonian period, which means that it had reached the bed of what had once been a Palæozoic ocean". This is the only official hint of what geological formation was actually penotrated at $7,000 \mathrm{ft}$., and is contained in a brief articlo published recontly in the Esso Magazine (autumn issue, 12, No. 4; 1963). This exploration well, actually at Broxmead Lane, $1 \frac{1}{2}$ miles north-east of Bolnoy village, was drilled by the Esso Petroleum Co., Ltd., to confirm results of geological and seismic surveys conducterd in this part of Sussex during the past two years. Unfortunately, it appears to have resulted in a dry hole, only gas shows at a comparatively shallow depth, as might have boen anticipated from previous knowledge, boing so far reported. However, what this venture may have lost in money and commercial oil results, the information it must have provided will prove of the greatest value in ultimate stratigraphical and, it is hoped, tectonic interpretations of the vertical section here deep in the heart of the central Weald. That the results of this borehole will lead to a re-assessment of oil and gas possibilities in Mesozoic and Palæozoic rocks lying beneath Sussex, if not of farther afield, is a safe guess.

In due course we may hope that the detailed log of the Bolney well will be published. These sort of pioneer adventures may understandably be treated as highly confidential at the time, especially when competitive oil interests in southern England are considered. But results are apt to remain in these circumstances buried in the archives, then forgotten for long afterwards, until a futuro generation has reason to seek to disinter vital data in appropriate geological investigations. None the less, however, there are some intriguing deductions, if not 'pointers'. stemming from the clue of marine Devonian strata at $7,000 \mathrm{ft}$., as affecting the stratigraphical succession and structure of the rocks below Bolney, even if actual or potential oil and gas horizons yet remain elusive. Writing on the "Concealed Strata-Palweozoic Systems" of the Weald, F. H. Edmunds (1954) says: "A.t the presont day the general surface of the Palaeozoic rocks is that of an inclined plane, with a slope southward of about 1 in 50 . i.e. a littlo over ono degree; Palaeozoic rocks beneath London oceur at about $1,000 \mathrm{ft}$. bolow soa-level; at Hellingly about $3,250 \mathrm{ft}$., at Penshurst about 4,550 ft., and at Henfield 4,850 ft., respectively below soa-level". Again, "It is noteworthy that at Penshurst, Jurassie rocks rest on Carboniforous Limestone, whilst at Hellingly and Henfield, the Palaeozoic surface is probably composed of Uppor Coal Measures; these facts point to an eroder surface of foldod rocks". The north-east-south-west straight-line distance betwoen Ponshurst and Henfield is about 26 miles; Bolnoy site is 6 miles along this line north-east of Henfield. The Palæozoic floor (surface) would on the basis of the foregoing data be anticipated at around $-4,780 \mathrm{ft}$. O.D. Thus interpreted, it would appear that, finishing at a depth of more than $8,000 \mathrm{ft}$. , it presupposes a determined minimum penetration of some $3,000 \mathrm{ft}$. of Palæozoic rocks here in the search for oil, it most hazardous vonture unless purely geological informa- 